\title{
Enucleation of ulcerated gastric lipoma after massive melaena
}

\author{
Raquel Lalanda 지, Rosa Suárez González
}

General Surgery, Centro Hospitalar do Médio Tejo EPE, Tomar, Portugal

\section{Correspondence to} Dr Raquel Lalanda; raquellalanda@gmail.com

Accepted 19 July 2021

\section{DESCRIPTION}

A 79-year-old man with medical history of coronary artery disease and atrial fibrillation treated with anticoagulant drugs was admitted to the emergency department with an episode of massive gastrointestinal haemorrhage presenting as melaena. On examination, he was haemodynamically unstable. The abdomen was painful on the upper quadrants and rectal examination confirmed melaena. Analysis revealed a haemoglobin level of $50 \mathrm{~g} / \mathrm{L}$. The patient was stabilised with supportive measures and two-unit red blood cells transfusions. The posttransfusion haemoglobin level was $90 \mathrm{~g} / \mathrm{L}$. Upper endoscopy revealed submucosal ulcerated tumour arising from the antrum. The CT scan revealed a well-encapsulated and fat-attenuated lesion $(-90$ Hounsfield units) in the gastric antrum, measuring $6.2 \times 3.3 \mathrm{~cm}$ (figure $1 \mathrm{~A}$ and video 1). Endoscopic ultrasound confirmed the presence of submucosal hyperechoic lesion measuring $9 \times 4 \mathrm{~cm}$ without evidence of perigastric lymph node enlargement (figure 1B). Biopsy was inconclusive. The patient underwent gastrotomy with tumour enucleation (figure 2). Postoperative recovery was uneventful. There was no bleeding recurrence during follow-up.

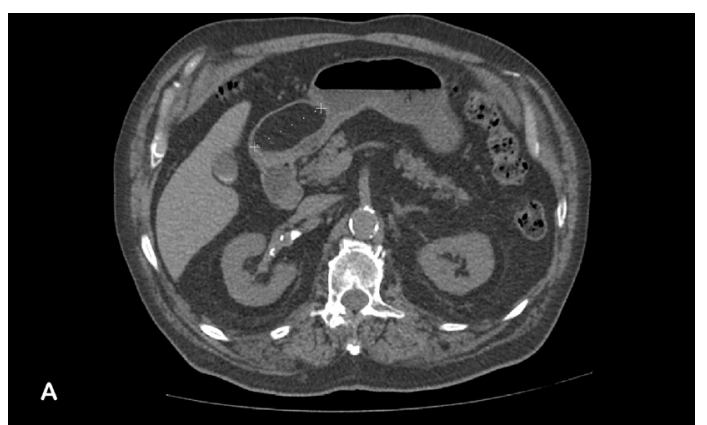

Check for updates

(c) BMJ Publishing Group Limited 2021. No commercial re-use. See rights and permissions. Published by BMJ.

To cite: Lalanda $\mathrm{R}$ Suárez González R. BMJ Case Rep 2021;14:e244686. doi:10.1136/bcr-2021244686

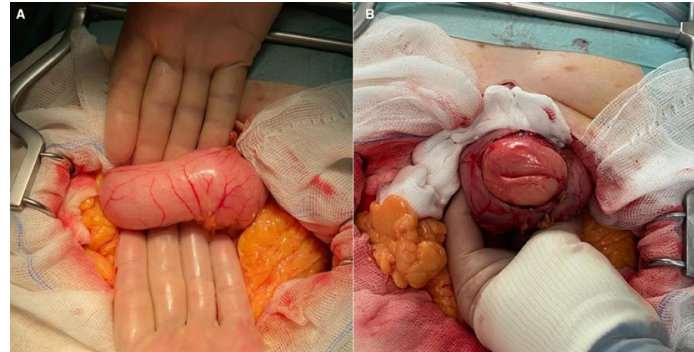

Figure 2 (A) Stomach wall showing the position of the lipoma. (B) Gastrotomy with tumour enucleation.

Histological examination confirmed the diagnosis of submucosal lipoma with $9.5 \times 4.8 \times 2.5 \mathrm{~cm}$ and ulceration.

Lipomas account for $1 \%-3 \%$ of all gastric tumours. ${ }^{1-3}$ They represent $5 \%$ of all gastrointestinal tract lipomas. ${ }^{2}$ Lipomas are mainly found in women. ${ }^{4}$ They are most prevalent between the fifth and seventh decades of life. ${ }^{4}$ Gastric lipomas are usually solitary. ${ }^{4}$ In $75 \%$ of cases, they are found in the antrum but can arise from every part of the stomach. ${ }^{45}$

Small lipomas $(<2 \mathrm{~cm})$ are usually asymptomatic and can be incidentally identified during a radiological or endoscopic examination. ${ }^{2}$ Larger ones $(>4 \mathrm{~cm})$ can manifest clinically with gastric outlet obstruction, gastroduodenal intussusception or upper gastrointestinal bleeding due to mucosal erosion. ${ }^{1246}$

Upper gastrointestinal endoscopy usually reveals a submucosal mass with three signs that help establishing the diagnosis: pillow sign, tenting sign and a naked fat sign. ${ }^{1}$ Most lipomas are submucosal (95\%), which means regular mucosa biopsies are inconclusive. ${ }^{3}{ }^{46}$ Endoscopic ultrasound reveals a hyperechoic, homogeneous and well-circumscribed submucosal lesion. ${ }^{17}$ CT scan reveals a wellcircumscribed homogeneous submucosal mass with an attenuation value of -70 to -120 Hounsfield units which is pathognomonic of gastric lipomas. ${ }^{89}$

Simple excision of the lesion is usually adequate since recurrence rates are low. ${ }^{9}$ Asymptomatic and indolent gastric lipomas can be managed without intervention. ${ }^{310}$ Large $(>4 \mathrm{~cm})$ and symptomatic tumours were traditionally treated with laparoscopic or open surgery such as enucleation or even partial gastrectomy. ${ }^{1} 1011$ Nowadays, endoscopic submucosal dissection (ESD) has become a technically feasible and safe alternative to conventional surgery for removal of large lipomas. ${ }^{12-14}$ Nevertheless, a case of obstructive symptoms has recently been reported after a large lipoma $(8 \times 6 \mathrm{~cm})$ 


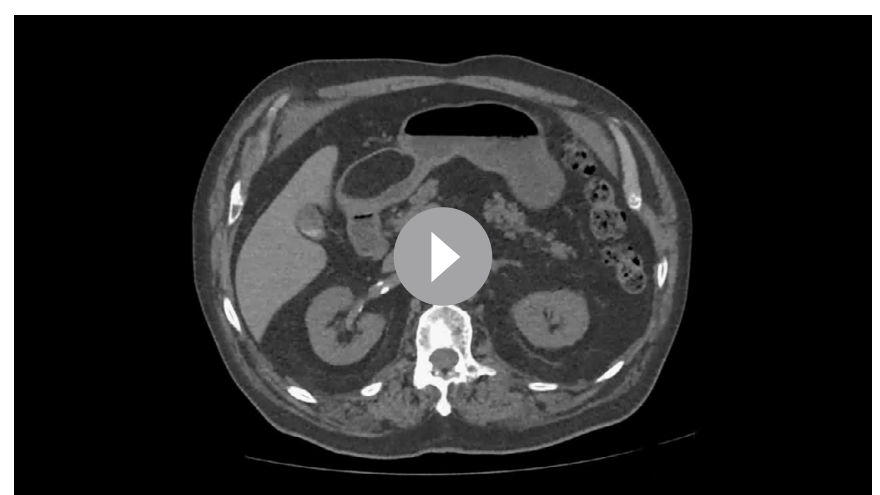

Video 1 CT scan axial view revealing a well-encapsulated and fatattenuated lesion in the gastric antrum.

resected with ESD was left in the stomach for digestion by gastric secretions. ${ }^{15}$

Our patient underwent gastrotomy with enucleation of a submucosal ulcerated lipoma with $9.5 \times 4.8 \times 2.5 \mathrm{~cm}$ after an episode of massive gastrointestinal haemorrhage. In certain cases, however, endoscopic removal offers a less invasive option with quicker recovery compared with laparoscopic or open surgery. ${ }^{14}$

\section{Learning points}

- Small gastric lipomas $(<2 \mathrm{~cm})$ are usually asymptomatic and can be incidentally identified during a radiological or endoscopic examination. Larger gastric lipomas ( $>4 \mathrm{~cm}$ ) can manifest with upper gastrointestinal bleeding due to mucosal erosion, gastric outlet obstruction or gastroduodenal intussusception.

- CT scan revealing a well-circumscribed homogeneous submucosal mass with an attenuation value of -70 to -120 Hounsfield units is considered pathognomonic of a gastric lipoma.

- Asymptomatic and indolent gastric lipomas can be managed without intervention, while symptomatic lesions should be removed by endoscopy or surgery.

Contributors RL: substantial contributions to the conception of the work; drafting the work and revising it critically for important intellectual content; final approval of the version to be published; agreement to be accountable for all aspects of the work in ensuring that questions related to the accuracy or integrity of any part of the work are appropriately investigated and resolved. RSG: substantial contributions to the conception of the work; revising it critically for important intellectual content; final approval of the version to be published; agreement to be accountable for all aspects of the work in ensuring that questions related to the accuracy or integrity of any part of the work are appropriately investigated and resolved.

Funding The authors have not declared a specific grant for this research from any funding agency in the public, commercial or not-for-profit sectors.

Competing interests None declared.

Patient consent for publication Next of kin consent obtained.

Provenance and peer review Not commissioned; externally peer reviewed.

ORCID iD

Raquel Lalanda http://orcid.org/0000-0002-6430-1078

\section{REFERENCES}

1 Sabbah M, Nakhli A, Helal I, et al. Gastrointestinal bleeding as an initial manifestation of gastric lipoma: case report and review of the literature. Clin Case Rep 2020;8:1988-92.

2 Chagarlamudi K, Devita R, Barr RG. Gastric lipoma: a review of the literature. Ultrasound Q 2018:34:119-21.

3 Parreira R, Rama T, Eloi T, et al. Enucleation of a giant symptomatic gastric lipoma, a safe surgical approach. J Surg Case Rep 2021;2021:rjab087.

4 Termos S, Reslan 0, Alqabandi 0, et al. Giant gastric lipoma presenting as Gi bleed: enucleation or resection? Int J Surg Case Rep 2017;41:39-42.

5 Cappell MS, Stevens CE, Amin M. Systematic review of giant gastric lipomas reported since 1980 and report of two new cases in a review of 117110 esophagogastroduodenoscopies. World J Gastroenterol 2017;23:5619-33.

6 Georgiev A, Tsvetkova S, Aleksova L, et al. Gastric lipoma of the pylorus - case report of an incidental finding. Radio/ Case Rep 2021;16:1882-4.

7 Dias de Castro F, Magalhães J, Monteiro S, et al. The role of endoscopic ultrasound in the diagnostic assessment of subepithelial lesions of the upper gastrointestinal tract. GE Port J Gastroenterol 2016;23:287-92.

8 Sullivan IW, Hota P, Dass C. Gastric lipomas: a case series and review of a rare tumor. BJR Case Rep 2019;5:20180109.

9 Krishnaraj B, Dhanapal B, Shankar G, et al. Gastric lipoma: a rare cause of haematemesis. Ann R Coll Surg Engl 2018;100:e41-3.

10 Mir AS, Kesar V, Sageer M, et al. Bleeding gastric lipoma resected by endoscopic submucosal dissection. Cureus 2020;12:e8909.

11 Pennisi D, Troian M, Nagliati C, et al. Totally laparoscopic transgastric resection of a gastric submucosal Fibrolipoma and concomitant sleeve gastrectomy in a morbidly obese patient. Obes Surg 2020;30:4679-80.

12 Tada N, Kobara H, Masaki T. Modified endoscopic unroofing enucleation using nylon ring traction for a large gastric lipoma. Dig Endosc 2021;33:e34-5.

13 Han S, Cristin D, Reveille RM, et al. Large gastric lipoma with lipomatous ulceration resulting in gastrointestinal bleeding managed with endoscopic submucosal dissection. ACG Case Rep J 2019;6:e00212.

14 Ingason AB, Theodors A, Agustsson AS, et al. Giant gastric lipoma successfully removed by endoscopic submucosal dissection: case report and systematic review. Scand J Gastroenterol 2018;53:1018-24.

15 Grande G, Pigò F, Caruso A, et al. Too big to go out: gastric endoscopic submucosal dissection of giant lipoma complicated by intestinal obstruction. Endoscopy 2021. doi:10.1055/a-1346-8122. [Epub ahead of print: 04 Feb 2021].

Copyright 2021 BMJ Publishing Group. All rights reserved. For permission to reuse any of this content visit

https://www.bmj.com/company/products-services/rights-and-licensing/permissions/

BMJ Case Report Fellows may re-use this article for personal use and teaching without any further permission.

Become a Fellow of BMJ Case Reports today and you can:

- Submit as many cases as you like

- Enjoy fast sympathetic peer review and rapid publication of accepted articles

- Access all the published articles

- Re-use any of the published material for personal use and teaching without further permission

Customer Service

If you have any further queries about your subscription, please contact our customer services team on +44 (0) 2071111105 or via email at support@bmj.com.

Visit casereports.bmj.com for more articles like this and to become a Fellow 